\title{
Guias de Viagem e de Turismo da Cidade de São Paulo (1924 e 1954): hospitalidade e patrimônio ${ }^{1}$
}

\author{
Travelling Around the Land of Drizzle - Sao Paulo: culture and heritage in the travel books \\ of the city (1924 and 1954)
}

Guías de Viaje y de Turismo de la Ciudad de Sao Paulo (1924 y 1954): hospitalidad y patrimonio

\author{
Sênia Regina Bastos $^{2}$ \\ Madalena Rodrigues Nova ${ }^{3}$
}

\begin{abstract}
Resumo
O artigo contempla a análise de dois guias de viagem e de turismo da cidade de São Paulo, impressos e editados em português, em dois momentos distintos (1924 e 1953), de forma a identificar as possibilidades de visitação, sugestões de entretenimento e as informações necessárias aos deslocamentos dos viajantes, visitantes ou moradores. Instrumento da hospitalidade, cujo ato envolve ações como recepção, hospedagem, restauração e entretenimento, os guias apresentam aspectos próprios à hospitalidade urbana, informam o visitante, mostrando o que de melhor há na "cidade da garoa". Trata-se de uma fonte privilegiada para a história de São Paulo ao evidenciar o imaginário cultural do período no qual se inscreve, selecionar edificações e monumentos e valorizar determinadas regiões da cidade.
\end{abstract}

Palavras-chave: história do turismo; guia de viagem; patrimônio histórico.

\begin{abstract}
The article contemplates the analysis of two travel books of Sao Paulo, printed and edited in Portuguese, in two distinct moments (1924 and 1953), so as to identify the visitation possibilities, entertainment options, and the necessary information about shuttling and commuting, be it for visitors or for dwellers. As a hospitality instrument, thus involving acts of

\footnotetext{
${ }^{1}$ O presente artigo foi elaborado a partir da dissertação de mestrado "Viagem e turismo: os guias da cidade de São Paulo - 1924 e 1954" (NOVA, 2009).

${ }^{2}$ Doutora em Historia pela Pontifícia Universidade de São Paulo (PUC-SP); Docente da Universidade Anhembi Morumbi. Email: senia@anhembimorumbi.edu.br.

${ }^{3}$ Mestre em Hospitalidade pela Universidade Anhembi Morumbi. Email: marnova@gmail.com.
} 
reception, lodging, restoration, and entertainment, the travel books in question assay aspects inherent to the urban hospitality, informing the visitor as to what the land of drizzle has best to offer. It is a privileged source for the historical study as it evidences the cultural imaginary of the given period, selects buildings and monuments, and values some regions of the city.

Keywords: tourism history; travel book; historic heritage.

\section{Resumen}

El artículo incluye el análisis de dos guías de viaje y turismo de la ciudad de Sao Paulo, impreso y publicado en portugués, en dos momentos diferentes (1924 y 1953) con el fin de identificar las posibilidades para los visitantes, sugerencias de entretenimiento y información necesario a los cambios de los viajeros, visitantes o residentes. Instrumento de la hospitalidad, cuya acción implica acciones tales como la recepción, el alojamiento, la restauración y el entretenimiento, los guías tienen aspectos peculiares de la hospitalidad urbana, informar al visitante, mostrando lo mejor de la ciudad conocida como "ciudad de la llovizna". Esta es una fuente primaria para la historia de Sao Paulo, al mostrar la imaginación cultural de la época a la que se utiliza, seleccionar edificios y monumentos y promover determinadas zonas de la ciudad.

Palabras clave: historia del turismo; guía de viaje; patrimonio.

\section{Introdução}

Os guias de viagem e de turismo constituem importantes fontes para a escrita da história do turismo de uma cidade e expressam a noção de patrimônio própria ao período em que se inscreve. Tais fontes compreendem imaginários próprios da época em que foram elaborados, apresentam lugares notáveis, logradouros históricos, edificações associadas à identidade do destino "graças ao espelho que fornece de si mesmo e ao contato que ele permite com o outro" (POULOT, 2009, p. 14). Nesse sentido permitem a reflexão sobre os bens que gradativamente são incorporados às novas edições, indicando as reformulações da identidade cultural construída sobre o destino, bem como o desenvolvimento do turismo nessa localidade.

O presente artigo tem como fonte de pesquisa o mais antigo guia de viagem disponível para consulta, o Guia Illustrado do Viajante, de 1924, e o Guia Turístico da Cidade de São Paulo e 
seus Arredores, das Edições Melhoramentos, escrito e editado em 1953, cuja metodologia de análise das duas publicações apoia-se na análise de conteúdo (BAUER, 2002). A abordagem contemplou a organização interna dos guias, a permanência ou não das sugestões dos atrativos e lugares para visitação de moradores ou viajantes, bem como o surgimento de novas opções, cotejando-se as duas obras.

Em 1924 estima-se que havia cerca de 580 mil moradores, dos quais 35\% eram imigrantes, a cidade acabara de presenciar a Semana de Arte Moderna e vivenciara o Centenário da Independência, época em que o Brasil procurava "firmar-se" como nação livre e "construir" uma "identidade". Na década de 1950, São Paulo consolidava uma identidade fundamentada em seu crescimento urbano, com cerca de 3,5 milhões de habitantes, e pujança econômica, divulgando-a em um grande evento comemorativo de seus quatrocentos anos (LOFÊGO, 2004).

O primeiro guia analisado, editado por Monteiro Lobato \& Cia. em 1924, contemplou monumentos erigidos para as comemorações do Centenário da Independência, mas a preocupação maior de Jacintho Silva ${ }^{4}$, seu autor, era mostrar como "funcionava a cidade", dar informações às pessoas, viajantes ou moradores. Este não se preocupou em comentar os eventos, ou o seu legado (monumentos, logradouros especialmente preparados para as festividades etc.), mas sim em falar da arquitetura das edificações, a localização e o acesso aos lugares por ele considerados importantes e dignos de visitação na época.

As comemorações do Centenário da Independência mobilizaram o país. Além da cidade de São Paulo (SP) e da Capital Federal (RJ), foram inaugurados monumentos comemorativos em algumas cidades paulistas em alusão ao centenário, "a cidade quis tornar-se bela e apreciada e finalmente despertou num desejo de agradar (ANDRADE 1920 apud AMARAL, 1988, p. 87)". Por ocasião da publicação do guia, tais bens já se encontravam incorporados às trajetórias de seus moradores, tendo sido incorporados à publicação. Trata-se de um período

\footnotetext{
${ }^{4}$ Jacintho Silva foi assistente chefe de Julien Lansac, administrador da Casa Garnier até 1903. Trabalhou na Casa Garraux como administrador de livros e se instalou com estabelecimento próprio em 1919, com a casa Editora O Livro, que passou a ser ponto de encontro dos modernistas. As obras ali publicadas, a exemplo de Menotti del Picchia e Cassiano Ricardo e de outros autores como Taunay e Alfredo Pujol, eram impressas em pequenas edições, de cerca de mil exemplares (HALLEWELL, 2005).
} 
de mudanças para o país, sobretudo, no que diz respeito à definição de história e de identidade da nação. Identidade que será reelaborada e retomada por ocasião dos 400 anos da cidade.

O segundo guia ora analisado, o "Guia Turístico da Cidade de São Paulo e seus Arredores" (1953) inscreve-se no contexto dos preparativos da comemoração do IV Centenário da cidade de São Paulo e dos trabalhos de divulgação da comissão organizadora do evento. Escrito e editado por Edições Melhoramentos, informa com detalhes os monumentos e locais de visitação da cidade de São Paulo, além de abordar as cidades circunvizinhas e muitos bairros não existentes no primeiro guia, elenca também as novas construções destinadas a presentear a cidade pelo aniversário, como a do Parque Ibirapuera, a finalização da reforma do Teatro Municipal e da obra da Catedral da Sé. Essa festividade fundamentou-se em um projeto para revelar ao mundo uma grande cidade, de projeção internacional e para isto São Paulo se preparou. A Comissão do IV Centenário valorizou a data por meio de anúncios publicitários em jornais e revistas e elaborou um brasão para representá-la: "tratava-se de uma forma helicoidal - uma espiral - que se arrancava abruptamente do solo apontando para o céu, simbolizando a pujança da cidade" (MARINS, 2003, p. 23).

Os guias estudados mostram a cidade de maneiras diferentes, tendo em comum a preocupação de fornecer informações aos deslocamentos necessários, desde recepção, entretenimento, acomodação e restauração, ações que determinam hospitalidade, cada qual usando dos recursos disponíveis na época em que foram escritos e editados.

\section{A Origem dos Guias Turísticos}

Os guias turísticos são espaços peculiares de construção de narrativas (BARREIRA, 2005, p. 2), informam e mostram por meio de fotos e mapas os melhores lugares para se visitar, para restauração, ou para hospedagem, ou ainda, para fazer compras (os guias mais modernos trazem símbolos destinados a auxiliar o entendimento das informações quanto a preços e instalações) destacando-se o cuidado de alguns com a disponibilidade de textos bilíngues.

Barreira (2005) problematiza a legitimação de cenários e emblemas da memória social contemplados nos guias, tornando conhecidos os monumentos, edifícios e locais relevantes 
para a história da cidade. Todavia, há que se considerar o viés ideológico que tal seleção comporta e que não é explicitado por estas publicações. Disponibilizados em formatos de livros, folhetos explicativos ou catálogos, as informações ali contempladas variam de acordo com o momento social e político bem como ao território que extroverte, como se percebe nos guias analisados nesse trabalho. Infere-se que o guia turístico seja obra literária de interesse de turistas e viajantes, mas desperta a atenção também de pesquisadores, estudantes e profissionais de áreas de turismo, urbanismo, arquitetura e afins.

O guia turístico passou a ter esta denominação a partir da terceira década do século XIX, porém, na Antiguidade, existiram na Grécia os guias de viagens conhecidos como periegeses, considerados os precursores dos guias turísticos atuais. Nestes manuscritos encontravam-se informações sobre as cidades, monumentos, modos de vida e costumes de seus habitantes, eram utilizados pelos romanos em viagens à Grécia, sendo que o mais completo destes era Descrição da Grécia (Periegesis Hellados) escrito pelo viajante grego Pausânias, no período de 146 a 176. Na Idade Média existiram manuscritos do ano de 1.130 com o nome de Guia do Peregrino, destinados àqueles que faziam o caminho de Santiago de Compostela, na Galícia, hoje território espanhol (CAMARGO, 2002).

Camargo (2007) considera a literatura de viagens, escrita por europeus, no século XIX, incluindo guias, almanaques, anúncios de jornal, vinhetas e ilustrações como uma possibilidade de se constatar oferta e serviços disponíveis da época, o que potencializa essa modalidade de fonte para o estudo da história do Turismo no Brasil.

No século XVIII surgiu um tipo de viajante, o grand tourist, praticante do Grand Tour, expressão pela qual foram denominadas as viagens aristocráticas pelo continente europeu. $\mathrm{O}$ grand tourist foi descrito como amante da cultura dos antigos e de seus monumentos, além do gosto exacerbado por ruínas e contemplação de paisagens (SALGUEIRO, 2002).

O guia inglês para cavalheiros praticantes do Grand Tour ${ }^{5}$ era impresso, mas não se sabe em que escala e não se teve conhecimento de como era feita sua distribuição. $\mathrm{O}$ que deve ser

\footnotetext{
${ }^{5}$ O termo Grand Tour foi utilizado pela primeira vez em 1670, por Richard Lassels segundo Camargo (2002, p. $38)$.
} 
considerado é que eram guias de viagem especializados, identificados pela finalidade da viagem: peregrinações, estudos ou comércio (CAMARGO, 2002, p. 64).

Morgan-Proux (2006, p.111) chamou a atenção para a elaboração de cadernos com anotações feitas pelos guias intérpretes (neste caso, os profissionais) durante as viagens nas montanhas dos Alpes franceses, destacando a natureza dessas anotações, como a presença de encostas, montes e picos, modalidades de habitação, além de um pequeno vocabulário do idioma inglês. Acredita-se que tais cadernos escritos no século XVIII e não publicados podem ter servido como guias de viagem.

Muitos escritores ficaram conhecidos por seus romances históricos como Chateaubriand, Victor Hugo, o escocês Valter Scott, George Sand, Sthendhal, Rousseau, entre outros, cujas narrativas, além de divulgarem as localidades, motivaram gerações a conhecê-las. As paisagens presentes nessas publicações limitavam-se a reprodução de desenhos ou pinturas, porém, a partir do século XIX, surgiu a fotografia e desenvolveu-se a técnica e arte dos cartazes. Por sua vez, guias impressos surgiram no século XIX, e com o advento da locomotiva a vapor, a ideia de abrir nas estações de estradas de ferro uma banca de livros e jornais espalhou-se rapidamente, inicialmente em Londres e depois Paris, por volta de 1850 (CAMARGO, 2002, p. 65).

O primeiro guia editado por Karl Baedeker, referia-se à viagem pelo Reno, Rheinlande, por volta de 1830 e Thomas Cook, considerado o primeiro agente de viagens profissional, também lançou um guia, o Handbook of Trip.

Segundo Camargo (2007) o Brasil ganhou visibilidade na literatura de viagem a partir de 1808 com a transferência da família real para o Rio de Janeiro. Até o século XIX, os viajantes que por aqui passaram deixaram relatos que integraram a literatura de viagens constituindo uma "literatura de testemunhos", visto que descreviam suas próprias experiências. Tais escritos, passados de mão em mão, alimentavam narrativas extravagantes imaginárias e sobrenaturais acerca do Brasil (SCHWARCZ, 2004). 
O primeiro guia escrito e editado no Brasil pelo alemão Revert Henry Klumb ${ }^{6}$, inaugura a técnica fotográfica chamada estereocopia. Transferindo-se do Rio de Janeiro para Petrópolis tornou-se fotógrafo da família imperial, escreveu o guia intitulado "Doze Horas em Diligência: Guia Ilustrado do Viajante de Petrópolis a Juiz de Fora", iniciado em 1861 e finalizado em 1872. Segundo o próprio autor, o livro tinha por mérito somente o fato de ser o primeiro feito no país. Com 85 páginas e 29 litografias, produzidas a partir de fotografias tiradas por Klumb, elencam além das paisagens naturais, preços, horários de trem e outras curiosidades, acompanhando o viajante durante os 144 quilômetros de percurso entre Petrópolis e Juiz de Fora (SCARRONE, 2007).

\section{A Cidade de São Paulo}

No final do século XIX a "São Paulo da garoa" aspirava dotar-se de aparência europeia e, para tanto, introduziu elementos arquitetônicos e imigrantes europeus. A urbanização valorizou os espaços públicos com estrito disciplinamento das edificações: no centro velho predominava a feição europeia, e nos bairros aristocráticos da Cidade Nova, prevalecia o modelo americano "com uma crescente verticalização e ausência de normas rígidas para controle das alturas" (REIS, 2004, p. 189).

A fundação da cidade e a independência nacional foram os eventos considerados dignos de memória, mas, era necessário ressaltar o papel desempenhado pelas elites locais, regionais e do próprio país. A infraestrutura urbana melhorou, os serviços públicos modernizaram-se e o concreto armado passou a ser adotado nas edificações com criação de novas estradas e melhoria das antigas. A outra face desse processo de mudança se manifestou no lazer e na cultura, no desenvolvimento de novas práticas esportivas etc.

Na década de 1950 a cidade viveu um momento de grandes transformações do seu espaço e do aumento de sua população, em virtude das migrações, desta vez do Nordeste do país que buscavam em São Paulo possibilidades reais de empregos nas fábricas e na construção civil.

\footnotetext{
${ }^{6}$ Klumb chegou ao Brasil em 1852 e começou a trabalhar no Rio de Janeiro.
} 
Antes, concentrados no Triângulo (formado pelas ruas Direita, XV de Novembro, São Bento e adjacentes) e depois nas avenidas São João e Ipiranga, os locais para entretenimento e de vida noturna com cinemas, restaurantes e bares, ali permaneciam nos anos 1950. Alguns nomes como Bar Brahma (1948), Gigetto (1938) e Bar Léo (1940) já eram sugestões e permanecem ainda hoje.

Neste período, banhos de mar nas praias de Santos tornaram-se comuns, sobretudo, para os habitantes da cidade, que contaram com a extensão de algumas rodovias que iam para o litoral.

\section{Hospitalidade nos Guias de Viagens e Turismo}

O guia de viagem ou turístico estabelece a mediação entre o viajante ou morador e o destino, dando a este a informação necessária aos seus deslocamentos. Existem cidades onde as informações são oferecidas espontaneamente e permitem ao estrangeiro orientar-se sem dificuldades, encontrar o que procura sem perder tempo. Concorrem para isso o desenho da cidade e a urbanidade, a disposição de elementos gráficos por meio de comunicação visual, a cortesia e as informações verbais graciosamente fornecidas por seus moradores etc. A informação neste caso assemelha-se ao dom, oferecê-la e recebê-la é um mecanismo da hospitalidade (RAFFESTIN, 1997).

A frequência de visitantes na cidade nos remete às inquietações acerca da segurança, tanto do forasteiro quanto do morador, e da hospitalidade, espécie de dom temporário de um espaço e de iniciação aos laços sociais no destino. Elaboram-se regras para o forasteiro, que é admitido sob condições em territórios previamente delimitados e destinados à sua circulação (GRASSI, 2004, pp. 21-34)

As informações reunidas e sistematizadas nos guias atenuam eventuais conflitos na medida em que contemplam informações relevantes para o forasteiro que, munido de um exemplar, detém os caminhos a percorrer para uma boa estada na urbe, ou seja, ao dominar os seus códigos é bem recebido e a prática da hospitalidade encontra sua plenitude. 
O "Guia Illustrado do Viajante" informa sobre a cidade para o viajante que chega a São Paulo, que recebia, desde o final do século XIX, imigrantes do mundo todo. Dos quase 5 milhões que vieram para o Brasil, 2,5 milhões dirigiram-se para o estado de São Paulo. O autor demonstrou claramente sua preocupação com as pessoas, quando detalhou as informações sobre cada lugar e como chegar até ele, de forma a prover-lhes do essencial: alimentação e repouso, além de diversas modalidades de serviços e equipamentos existentes. Suas primeiras páginas são dedicadas aos viajantes, estrangeiros ou imigrantes, mas apesar de todo empenho na descrição, isto não significou que tenha logrado êxito em informar com segurança e possibilitar ao leitor conhecer a cidade de São Paulo considerando-se os aspectos: acessibilidade, legibilidade e identidade (GRINOVER, 2006).

Desde as informações mais simples como o fuso horário e a moeda local até as de acesso aos serviços de infraestrutura, saúde e educação podem ser encontradas no guia, contudo, no idioma local, ou seja, português. Considerando-se os que não conheciam o idioma e os iletrados, infere-se que a procura por este tipo de obra, embora fosse muitas vezes imprescindível, pode ter sido insignificante. Por outro lado, o guia contempla os monumentos, parques, jardins, igrejas, teatros e locais para visitação e entretenimento, o que sugere que a elite poderia interessar-se por este tipo de leitura, pois, além dos viajantes a negócios seria essa classe social a que dispunha de condições econômicas para empreender viagens por lazer e entretenimento ou para adquirir conhecimento.

Observando os aspectos destacados por Camargo (2003) sobre os domínios da hospitalidade, o guia contemplou, ainda, a relação dos meios de transportes e de hospedagem, nomeando-os por local (centro e proximidades de estações de trens) e por categoria (familiar ou para senhoras).

Encontram-se sugestões dos melhores restaurantes (geralmente, dentro dos hotéis), cafés, mas também, mercearias, feiras livres e o mercado público. Relacionou algumas informações sobre os governos federal, municipal e estadual (como endereços e atividades da competência de cada um deles) e completou com temas como religião e serviços públicos, terminando com outras informações úteis aos que pretendem deixar a cidade. O guia não contem mapas, 
apenas fotos, o que deve ser analisado a partir da tecnologia de impressão disponível no período, mas que não é objeto de análise no presente artigo.

O Guia Turístico da Cidade de São Paulo e seus Arredores enaltece a cidade, situa o leitor no momento histórico de sua publicação e retoma a sua história desde a fundação em 1554 . Preocupa-se em informar a densidade demográfica, dados geográficos, número de edifícios, veículos e comparando a cidade com grandes metrópoles enfatiza os seus atrativos, por ser um guia turístico. Contempla as informações necessárias aos deslocamentos do viajante como meios de transporte, de hospedagem, de restauração e de entretenimento. Os quatro mapas que acompanham o guia não são claros, sendo três deles desenhos e uma cartografia, na qual nota-se a falta de recursos ou mesmo detalhamento necessário para a compreensão das informações ali reunidas, contendo setenta e duas ilustrações.

Contempla nomes de bairros, os itinerários de ônibus, para a capital e o interior, os nomes dos bancos, das casas bancárias ${ }^{7}$, das companhias de transportes marítimas, das companhias aéreas (não existentes no guia de 1924) e tantos outros itens julgados importantes por seu editor.

\section{O Guia Illustrado do Viajante (1924)}

O guia ora analisado possui 360 páginas finas e amareladas, capa dura de cor vermelha e formato retangular no tamanho de $12 \times 16 \mathrm{~cm}$. Além da folha de rosto e do prefácio, seu texto divide-se em seis partes, cujo sumário é denominado por Índice Methódico. Dirige-se ao leitor de forma simples e direta, explicando o quanto fora difícil compor o livro e que este se destinava a servir de anfitrião e dar informações aos viajantes, exatamente nos termos e ortografia da época.

A primeira parte trata das informações de acessibilidade aos serviços e infraestrutura da cidade, locais para se visitar e divertir, instituições públicas e de ensino, meios de transportes,

\footnotetext{
${ }^{7}$ As casas bancárias diferenciavam-se dos bancos por terem um capital menor e por se organizaram sob a forma de sociedades limitadas, em geral identificadas pelo nome de seus proprietários, ao passo que os bancos eram tipicamente sociedades por ações. Em 1921, estabeleceu-se formalmente por meio do decreto $\mathrm{n}^{\circ} 14.728$, a diferença com base no valor do capital (SAES, 2004).
} 
locomoção e de comunicação, o modo de viver, aqui relativo à alimentação, proporcionando a todos, moradores ou visitantes, informações necessárias aos deslocamentos.

$\mathrm{O}$ autor preocupou-se com a acessibilidade: informa meticulosamente o número do bonde ou ônibus que trafega nos locais indicados, para que o visitante ou morador possa ter acesso aos serviços prestados na cidade, assim como os dados relativos à saúde, lazer e educação. Uma mesma edificação encontra-se citada mais de uma vez, em virtude da especificidade que evidencia, o que aponta para sua preocupação editorial, ou seja, a adoção de uma classificação previamente definida que fundamentou seu projeto.

No início da obra contempla anúncios publicitários, valoriza os monumentos e a arquitetura urbana, visto que no final do século XIX e início do século XX a cidade passou por grande transformação.

O capítulo sétimo é dedicado aos lugares mais bonitos da cidade, de acordo com o ponto de vista de Silva, onde os viajantes ou moradores passeavam e se entretinham, intitulado de Parques, Jardins e passeios. Cita e descreve o Parque Dom Pedro II, o Palácio das Indústrias e o Parque do Anhangabaú, o mais artisticamente delineado, e, ao que se refere ao jardim da esplanada: "embeleza e realça edifícios como do Teatro Municipal, da Delegacia Fiscal e da Prefeitura". Aponta também três trabalhos de arte: Le petit moulin (Di Palma), o Ceifador (Moreau) e Eva (Brecheret), o primeiro em bronze e os outros em mármore, numa forma de valorizar as esculturas presentes nos logradouros públicos. Menciona o monumento e o conjunto escultórico em homenagem a Carlos Gomes, de Luigi Brizzolara, inaugurado por ocasião das comemorações do Centenário da Independência, cuja iniciativa fora da colônia italiana sem, no entanto, destacar o evento, o que indica a objetividade de seu projeto editorial.

Destaque-se que nesse momento também foram inaugurados o monumento a Olavo Bilac, de Willian Zadig, e o Monumento à Independência, de Ettore Ximenes. Segundo Bastos e outros (1993, p. 1) tais inaugurações constituíram "Verdadeiras apoteoses [...], contaram com a participação da população que acorreu em massa para as cerimônias, incentivados por uma noção de patriotismo, carregada de ufanismo solene". Também citada, encontra-se a escultura 
em homenagem a Giuseppe Verdi, de Amadeu Zanni, doada pela colônia italiana e instalada no parque do Anhangabaú em 1921.

Silva descreve o Parque da Independência ainda em construção, já o comparando ao Parque de Versalhes. Lista as praças existentes: Antonio Prado, João Mendes, Sé, Princesa Isabel etc. e, sobre cada uma delas, informa a localização, destaca os monumentos, as esculturas e pontos de entretenimento, sem esquecer o número do bonde que dá acesso às mesmas. Os largos São Bento, Paissandu, Arouche, São Francisco, entre outros, merecem a mesma atenção por parte do escritor.

Reporta-se aos passeios ao Triângulo, trajeto compreendido entre as Ruas Quinze de Novembro, São Bento e Direita, verdadeiro centro comercial da cidade: "a rua Quinze é a rua dos bancos, a rua São Bento, da Bolsa de Mercadorias e Títulos e a rua Direita a rua da elegância e das casas de moda que atraía a elite feminina e o sexo forte aos sábados ".

As avenidas Paulista, Higienópolis, Angélica e o Jardim América também são citadas como sugestões de passeios, em virtude da suntuosidade e arquitetura das moradias, enquanto que os bairros de Ipiranga e Braz foram destacados por suas indústrias, casas e população (os operários). Discorre sobre a Avenida Independência em construção, avenidas Rangel Pestana e Celso Garcia até a Ponte Grande.

O oitavo capítulo dedicado também ao entretenimento contempla teatros, cinemas, concertos públicos, jogos de bilhares, danças, corridas de cavalos e esportes (natação, canoagem, futebol, ginástica etc.). Inicia-se por uma longa descrição do Teatro Municipal, interna e externa, onde, segundo o autor podiam ser vistos os melhores espetáculos internacionais. Reporta-se aos teatros Sant'Anna, Boa Vista, Apollo, além do Casino Antártica, quanto aos cinemas, lista o Cine Teatro República, Cine Triângulo e Cine Avenida, localizados no Centro e proximidades, e deteve-se nos concertos públicos ao ar livre, no Vale do Anhangabaú e no Jardim da Luz. Mereceram destaques o Club de Corridas Paulistano, atual Jockey Club, o Clube de Regatas Tietê, a Associação Atlética São Paulo, o Clube Esperia, além do Instituto Jaguaribe e a Piscina de Indianópolis, citou ainda o Sport Club Corinthians, Societá Sportiva Palestra Itália e o Clube Atlético Paulistano. 
Chamado de "Curiosidades a ver", o capítulo nono descreve os monumentos comemorativos, estátuas, hermas, obeliscos, palácios, edifícios religiosos e notáveis entre outras instituições. Inicia com o Museu Paulista e contempla os monumentos a Carlos Gomes, Alfredo Maia, Estátua de José Bonifácio e de Diogo Feijó, Herma de Dr. Cesário Motta e de Celso Garcia, bem como de Álvares de Azevedo e do Dr. João Mendes, o Obelisco do Piques entre tantos outros, assinalando a localização e, sempre que possível, esclarecendo o número do bonde ou outro meio de locomoção.

Os viadutos do Chá e o de Santa Ifigênia, as pontes Grande (Ponte das Bandeiras) e Pequena, o Canal do Ipiranga e o Rio Tamanduateí são destacados. Os palácios do Governo, da Justiça, das Indústrias, da Cúria Metropolitana, além de listados são detalhados. Na década de 1920 o Pátio do Colégio constituía espécie de centro cívico e palco de manifestações políticas ${ }^{8}$. Nesta época, a edificação projetada por Ramos de Azevedo, o Palácio do Governo ocupava o local, além da Secretaria de Agricultura e a Tesouraria da Fazenda, também do mesmo arquiteto.

Descreve criteriosamente os edifícios religiosos: Catedral Metropolitana de São Paulo, em construção; a Basílica Abacial de São Bento (compreende a basílica, o mosteiro e o ginásio), a Igreja de Santa Ifigênia, o Santuário do Sagrado Coração de Jesus, a Igreja Nossa Senhora da Glória, da Consolação, de Santo Antonio, de São Gonçalo, da Boa Morte etc., bem como templos de outros cultos, como as igrejas Methodista e Lutherana.

Evidencia como edifícios notáveis aqueles que mereceram destaque, por sua arquitetura ou por sua importância histórica: Penitenciária de São Paulo, Correios e Telégrafos, Faculdade de Direito, Escola Normal da Capital e Lyceu de Artes e Ofícios, o Hospital da Força Pública, Automóvel Club, Hospital da Santa Casa de Misericórdia, Beneficência Portuguesa, Teatro Municipal, Estação da Luz e Escola de Comércio Álvares Penteado, Faculdade de Medicina e Cirurgia de São Paulo, Escola Politécnica de São Paulo. Prosseguiu com os institutos Butantã, Bacteriológico, Higiene e Anatômico (da Faculdade de Medicina), Veterinário e laboratórios de Análises Clínicas e Bromatológicas, Farmacêutico, além do Desinfectório Central e a Escola de Farmácia e Odontologia. Quanto às instituições pias tiveram lugar os asilos para

\footnotetext{
${ }^{8}$ LOMONACO, Maria Aparecida. O Pátio do colégio: um lugar de muitas memórias. In: BUENO, Eduardo (org.) Os nascimentos de São Paulo. Rio de Janeiro: Ediouro, 2004, p. 132-133.
} 
inválidos e órfãos. Foram citados, seguidamente, os dois cemitérios mais importantes da cidade: Consolação e Araçá.

No capítulo décimo elenca os museus, as bibliotecas, demais exposições, colégios e faculdades públicas e particulares. Identifica todos os jornais e revistas brasileiros e estrangeiros distribuídos na capital.

A segunda parte trata da Administração, divide-se em oito capítulos e informa sobre o Governo do Estado, a Municipalidade e o Governo Federal. O capítulo quarto aborda o tema religião e o quinto, o comércio, assim como o sétimo reporta-se à saúde pública e o oitavo aos serviços funerários, repetindo muitas informações já citadas.

Na terceira parte repete as informações da chegada, destaca as exigências para emissão de passaporte aos que pretendem embarcar para ao exterior. A quarta parte da obra é destinada aos estrangeiros e considera a entrada no território nacional, seus direitos e deveres.

Na quinta parte reporta-se aos imigrantes e trata da Hospedaria dos Imigrantes, informa sua localização, descreve o serviço de povoamento do solo de São Paulo e do Patronato Agrícola.

Como não contem mapa, a sexta parte do guia contempla um dicionário de ruas com a indicação da localização, bairro, número do bonde, onde inicia e termina cada um dos logradouros, organizados em ordem alfabética.

\section{O Guia Turístico da Cidade de São Paulo e de seus Arredores (1953)}

O "Guia Turístico da Cidade de são Paulo e de seus Arredores" inscreve-se nas obras comemorativas do Quarto Centenário da Cidade de São Paulo em 1954. Sua capa mostra uma foto aérea da cidade, já verticalizada, em preto e branco. Composta de 200 páginas, mede 22 $\mathrm{cm} \times 12 \mathrm{~cm}$, contém 72 fotos e quatro mapas, sendo três desenhos e uma cartografia. O sumário divide-se em quatro partes: Descritiva, Informativa, Apêndice e Mapas e Plantas.

A parte descritiva é a de maior conteúdo, aborda aspectos históricos, geográficos, econômicos e políticos da cidade. Inicia-se com a ilustração do quadro de Benedito Calixto, representando Martim Afonso e sua expedição composta por colonos da capitania de São Vicente, índios e 
padres e descreve o trajeto percorrido do mar até o planalto onde foi celebrada a primeira missa, a 25 de janeiro de 1554, discorrendo por sua história desde então.

Ainda nesta primeira parte é destaque o Triângulo histórico, o aumento de casas comerciais incluindo-se hotéis, chapelarias, livrarias, bancos e casas bancárias. O Viaduto do Chá e o Vale do Anhangabaú, além de outros logradouros como ruas Líbero Badaró e Boa Vista, Avenida Nove de Julho e as praças Patriarca, das Bandeiras, dos Correios etc. são apresentados. Evidencia o crescimento do número de arranha-céus, de veículos, da população e o aumento significativo do número de bairros da cidade.

Quanto aos monumentos, elenca mais de 70 deles, detalhando-os, além de 30 igrejas, incluindo-se as católicas, evangélicas e outros cleros. Os passeios principais constituem sugestões: Horto Florestal, Parque da Água Branca, Parque da Cantareira, Pico e Parque do Jaraguá, Parque Siqueira Campos, Parque Dom Pedro II, Parque do Estado, Orquidário Silva Pinto, Jardim da Luz, Parque do Ibirapuera, Jardim Zoológico Agenor e cidades vizinhas, além das estações balneárias e climáticas, como Campos do Jordão, Guarujá, Águas da Prata, entre outras.

Na Parte Informativa repete algumas informações já fornecidas e as detalha. Nomeia os bairros, descreve o itinerário dos bondes e dos ônibus no perímetro urbano, evidencia o serviço de ônibus para o interior, relaciona os aeroportos, correios e telégrafos, feiras livres, hospitais, casas de saúde, postos policiais, repartições públicas, principais jornais, entre outros prestadores de serviços necessários aos moradores e visitantes. Sem precisar o critério da seleção, museus, galerias de antiguidade, exposições de arte, bibliotecas e discotecas, trinta clubes esportivos e sociais são citados, assim como os parques e jardins, cinemas, teatros, hotéis, restaurantes, churrascarias, cantinas, confeitarias e salões de chá, leiterias e bombonieres, que servem à cultura e ao entretenimento, de acordo com o guia. Também lista as associações e câmaras de comércio, as agências de turismo e de passageiros, as empresas de transportes marítimo e aéreo, ainda em pequeno número.

O Apêndice é um guia de conversação para viagens em português, com traduções em italiano, francês, alemão e inglês. 
Os mapas e plantas encontram-se distribuídos aleatoriamente no guia sendo que o primeiro, pequeno mapa para passeios, exibe em destaque a Faculdade de Medicina, o Cemitério do Araçá e o Estádio do Pacaembu. O segundo é uma planta dos pontos turísticos da cidade de São Paulo e contempla desenhos dos principais pontos de visitação. O terceiro mapa refere-se aos arredores de São Paulo, indica as saídas e as rodovias para acesso às cidades vizinhas. O quarto é um desenho exemplificando as principais ruas do centro da cidade, sem escalas ou qualquer precisão característica de uma cartografia ou mapa.

\section{Palimpsesto: à guisa de considerações finais}

Os dois guias têm propostas e correspondem a períodos distintos, o que equivale dizer, que apresentam duas cidades. Monumentos, museus, igrejas, restaurantes, meios de hospedagem e pontos turísticos são contemplados em ambos e verifica-se que alguns se repetem nos dois guias. Tais elementos remetem à reflexão sobre a singularidade do patrimônio evidenciado, especialmente ao que se refere às personalidades históricas, às edificações públicas e religiosas e, sobretudo, aos bens relacionados a cada contexto comemorativo: o Centenário da Independência do Brasil (1922) e o Quarto Centenário da Cidade de São Paulo (1954).

O conceito de patrimônio que fundamenta a atuação do Instituto do Patrimônio Histórico e Artístico Nacional nos seus primeiros anos de atuação (criado em 1937), valoriza a história, o catolicismo e o barroco (estilo arquitetônico) (RUBINO, 1999). Em certo sentido, percebe-se que os bens selecionados e valorizados nos dois guias encontram-se em sintonia com esse conceito de patrimônio vigente.

O primeiro guia analisado é um manual de informações aos moradores ou visitantes de toda a gama de serviços de utilidade pública, de lazer e entretenimento, além de apontar a riqueza da cidade de São Paulo, contemplada nas artes e na arquitetura, na cultura e nos esportes. O segundo guia destaca, sobremaneira, o crescimento da cidade e de sua população, sua história, o aumento das edificações, pontes e similares, embora não tenha deixado de se referir aos monumentos, à educação e aos esportes, pois tinha a necessidade de demonstrar a grandeza de São Paulo, em todos os setores, já que foi obra comemorativa do IV Centenário da cidade. 
Embora escrito e editado numa época de menos recursos tecnológicos, o guia de 1924 aproxima o indivíduo do espaço público com seus detalhes e minúcias, como se estivesse falando com o leitor e explicando-lhe o funcionamento da cidade, enquanto que o de 1953 preocupa-se em demonstrar os números da cidade que crescia a cada minuto, acabando por tornar-se a cidade que se conhece hoje.

Essa fonte permite a reflexão sobre a organização do turismo na cidade, contempla equipamentos de hospedagem, alimentação, transporte, atrativos e serviços inerentes à concretização desse setor. A presente análise evidencia os guias de viagem e de turismo como fonte de pesquisa, detalha-os, enfatiza sua potencialidade para novas leituras, como, por exemplo, para os estudos das práticas culturais e de lazer relacionadas à fruição dos equipamentos urbanos da cidade.

\section{Referências}

ANDRADE, 1920 apud AMARAL, Aracy. Artes plásticas na Semana de 1922. São Paulo: Editora 34, 1988, p. 87.

BARREIRA, Irlys Alencar Firmo. Os guias turísticos em Berlim. Tempo Social. Revista de Sociologia da USP, v. 17, nº 1, 2005, p. 2.

BASTOS, Sênia, CHOHFI, Amanda Girardi, RAMOS, Antonio Martins, ROSA, Priscila Helena. $O$ monumento a Carlos Gomes. São Paulo, manuscrito, 1993, p. 1.

BAUER, Martin W. Análise de conteúdo clássica: uma revisão. In: BAUER, Gaskel. Pesquisa qualitativa em imagem e som. Petrópolis: Vozes, 2002.

CAMARGO, Haroldo Leitão. Patrimônio histórico e cultural. São Paulo: Aleph, 2002.

CAMARGO, Haroldo Leitão. Uma pré-história do Turismo no Brasil: recreações aristocráticas e lugares burgueses. São Paulo: Aleph, 2007.

CAMARGO, Luiz Otávio de Lima. Os domínios da hospitalidade. In: DENCKER, Ada de Freitas Maneti e BUENO, Marielys Siqueira (org.). Hospitalidade: cenários e oportunidades. São Paulo: Pioneira Thomson Learning, 2003.

GRASSI, Marie-Claire. Hospitalité. Passer le seuil. MONTADON, Alain (dir). Le livre de l'hospitalité. Accueil de l'étranger dans l'histoire et les cultures. Bayard: Paris, 2004, p. 21-34.

GRINOVER, Lúcio. A hospitalidade urbana: acessibilidade, legibilidade e identidade. Revista Hospitalidade, ano III, no 2 p. 29-50, São Paulo: Anhembi-Morumbi, 2006.

GUIA Turístico da Cidade de São Paulo. São Paulo: Edições Melhoramentos, 1953.

HALLEWELL, Laurence. O livro no Brasil: sua história. São Paulo: Edusp, 2005. 
LOFÊGO, Silvio Luiz. IV centenário da cidade de São Paulo: uma cidade entre o passado e o futuro. São Paulo: Annablume, 2004.

LOMONACO, Maria Aparecida. O Pátio do colégio: um lugar de muitas memórias. In: BUENO, Eduardo (org.) Os nascimentos de São Paulo. Rio de Janeiro: Ediouro, 2004, p. 132-133.

MARINS, Paulo César Garcez. O Parque do Ibirapuera e a construção da identidade paulista. Anais do Museu Paulista: história e cultura material. São Paulo, vol. 6/7, n. 7. 2003, p. 23.

MORGAN-PROUX, Catherine. A hospitalidade dos guias intérpretes e o desenvolvimento turístico duradouro. Revista Hospitalidade. São Paulo, ano III, nº 2, $2^{\circ}$ sem. 2006, p.111.

NOVA, Madalena. Viagem e turismo: os guias da cidade de São Paulo (1924 e 1954). Dissertação (Mestrado em Hospitalidade). São Paulo: Universidade Anhembi Morumbi, 2009.

POULOT, Dominique. Uma história do patrimônio no Ocidente. São Paulo: Estação Liberdade, 2009, p. 14.

RAFFESTIN, Claude. Réinventer l'hospitalité. Communications. Editions du Seuil, nº 65, p.165-174, 1997.

REIS, Nestor Goulart. São Paulo: vila, cidade, metrópole. São Paulo: Qualis Editora e Comunicação, 2004, p. 189.

RUBINO, Silvana. O mapa do Brasil no passado. Revista do Patrimônio Histórico e Artístico Nacional. $\mathrm{n}^{\circ} 28,1999$.

SAES, Flávio. São Paulo republicana: vida econômica. In. PORTA, Paula (org.) História da cidade de São Paulo: a cidade na primeira metade do século XX. São Paulo: Paz e Terra, 2004.

SALGUEIRO, Valéria. Grand Tour: uma contribuição à história do viajar por prazer e por amos à cultura. Revista Brasileira de História São Paulo, v. 22, n 44. São Paulo, 2002.

SCARRONE, Marcello. Doze horas numa diligência. Revista de História da Biblioteca Nacional. Rio de Janeiro, Edição nº 27, dez. 2007.

SCHWARCZ, Lilia Moritz. A construção de uma identidade paulista. In: BUENO, Eduardo (org.) Os nascimentos de São Paulo. Rio de Janeiro: Ediouro, 2004.

SILVA, Jacyntho. Guia ilustrado do viajante. São Paulo, Monteiro Lobato, 1924.

\section{Recebido em: 24/03/2011}

Aprovado em: $26 / 04 / 2011$ ( $1^{\text {a }}$ versão) $17 / 08 / 2012$ ( $2^{\text {a }}$ versão) 